\title{
Phytoremediation of Chromium From Electroplating Effluent Treatment Plant (ETP) Sludge Using Helianthus annuus L.
}

\author{
SURESH, M. J. and RAJIV P.* \\ Department of Biotechnology, Karpagam Academy of Higher Education, Eachanari post, \\ Coimbatore 641-021, Tamil Nadu, India. \\ ${ }^{*}$ Corresponding author E-mail : rajivsmart15@gmail.com \\ http://dx.doi.org/10.13005/ojc/340638
}

Received: August 19, 2018; Accepted: November 27, 2018)

\begin{abstract}
Phytoremediation is one of the best methods in the treatment of sludge from industries because the pollutants present in the sludge are the food source for plants. So, the present study dealt with wedging the electro-plated sludge with red soil for 30 days and using it for the growth of Helianthus annuus $\mathrm{L}$. The sludge and soil were blended in different concentrations $\mathrm{C} 1, \mathrm{C} 2, \mathrm{C} 3$, $\mathrm{C} 4, \mathrm{C} 5$ and $\mathrm{C} 6$ (for the pre-treatment). Physicochemical parameters $(\mathrm{pH}$, ammoniacal nitrogen, potassium and phosphate) and heavy metals ( $\mathrm{Ar}, \mathrm{Cd}, \mathrm{Pb}, \mathrm{Hg}, \mathrm{Ni}$ and $\mathrm{Cr}$ ) of raw sludge, soil and ETP-treated-sludge with soil were analysed. After inspecting the physicochemical parameters of raw sludge and treated sludge, the soil-treated-sludge was used for the growth of Helianthus annuus L. Phytoremediation by Helianthus annuus L. has made considerable changes in the physicochemical properties of the soil, specially denoting the reduction of chromium. Thus, the work concludes that the pre-treated sludge provides a pathway for the uptake of heavy metals through the process of phytoremediation.
\end{abstract}

Keywords: Phytoremediation, Sludge, Chromium, Helianthus annuus L.

\section{INTRODUCTION}

The development of technology and industries leads to the production of new materials and products, which cause pollutions that are very harmful to the environment. The wastes produced by the industries cause numerous problems to soil and water resources. These wastes contain heavy metals like cadmium, zinc, lead, chromium, nickel, copper, vanadium, platinum, silver, and titanium ${ }^{1}$. Most of the wastes from industries are let into the soil and water courses directly. The wastes are degradable and non-degradable. Some microorganism can degrade the wastes, which takes a long time. Some toxic wastes are non-degradable. Heavy metals are important for living things at low concentration for their growth and metabolism. At high levels heavy metals are harmful, toxic, carcinogen and allergen. They can render inactive sensitive enzymes ${ }^{2}$.

Chromium is present in most of the industrial wastes (textiles, tanneries, steel and cement manufacturing industries) that are directly let into the environment affecting the health of living

This is an Open Access article licensed under a Creative Commons license: Attribution 4.0 International (CC- BY). Published by Oriental Scientific Publishing Company @ 2018

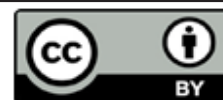


organism ${ }^{3}$. Concentration $\mathrm{Cr}$ in soil is 0.1 to $250 \mathrm{ppm}$ or even $400 \mathrm{ppm}$ depending on the geographical area $^{4}$. The stable forms of $\mathrm{Cr}$ in environment are tri and hexavalent. These $\mathrm{Cr}$ ions are obtained from industrial wastes to environment (Halides, oxides and sulphides) $)^{5}$.

The disposal of untreated wastes from industries increases heavy metal levels in the soil and health issues ${ }^{6}$. Nowadays it is one of the most uncontrollable problems for farmers. So, a proper technique is needed to control metals in soils ${ }^{7}$. Solidification, stabilization, landfill, excavation, vitrification, incineration, washing, flushing and electro kinetic systems are the methods used to control the heavy metals in the environment which have their own specificity and limits ${ }^{8}$.

Phytoremediation is the best technique to solve this problem which is eco-friendly and costeffective $^{9}$. In this method heavy metals are eliminated or controlled by plants ${ }^{10}$. The methods involved in phytoremediation are stimulation of microbes, degradation, accumulation or extraction, volatilization and stabilization ${ }^{11}$. When compared to others it is a low cost green technology ${ }^{12}$. The application of this method cleans the soil and water and the residues can be recycled without causing much damage to the environment ${ }^{13,14}$. In this present investigation electroplating effluent treatment plant (ETP) sludge was treated using Helianthus annuus.

\section{MATERIALS AND METHODS}

\section{Collection of electroplated sludge and analysis of physicochemical parameters}

Electroplated sludge was collected from the Lakshmi Machine Works (Latitude 10.603 and Longitude 77.378) located adjacent to Kaniyur village, Coimbatore. The collected sludge was stored at room temperature on PVC bags for a day. By the next day, physicochemical parameters of the sludge such as $\mathrm{pH}$, ammoniacal nitrogen, potassium, phosphate and heavy metals ( $\mathrm{Ar}, \mathrm{Cd}, \mathrm{Pb}, \mathrm{Cr}, \mathrm{Hg}$, and $\mathrm{Ni})$ were assessed using standard methods ${ }^{15}$.

\section{Collection of seeds and soil}

The seeds of Helianthus annuus were collected from the Department of Oil Seeds, Agricultural University, Coimbatore. Red soil was collected from $0-5 \mathrm{~cm}$ depth on the field of
Kenathukadavu (10.82 $\left.{ }^{\circ} \mathrm{N}, 77.02{ }^{\circ} \mathrm{E}\right)$, total area $9 \mathrm{~km}^{2}$, Coimbatore.

\section{Pre-treatment}

The collected electroplating sludge was pre-treated with red soil in the following ratio. The control (C1) is pure red soil, soil and sludge in the ratio of 8:2 (C2), soil and sludge in the ratio of $6: 4$ (C3), soil and sludge in the ratio of 4:6 (C4), soil and sludge in the ratio of 2:8 (C5) and the collected sludge (C6). The physicochemical parameters of soil, pre-treated sludge (C2, C3, C4 and C5) and the sludge (C6) were analysed after the incubation period of 30 days. This pre-treated sludge was further used for the growth of Helianthus annuus L. Ten seeds of Helianthus annuus were sown on a $12 \mathrm{~L}$ clay pot which was filled with pre-treated sludge. The percentage of seed germination was measured after 7 and 14 DAS. The plant growth (root length, shoot length, dry weight and fresh weight of plant) was determined after 30,60 and 90 DAS. Table 1 shows the physicochemical properties of soil and ETP sludge.

\section{Estimation of chlorophyll}

Chlorophyll ( $a$ and $b$ ) was estimated according to Arnon, 1949 (16). $5 \mathrm{~g}$ of fresh plant leaf sample was taken and homogenized in tissue homogenizer with $10 \mathrm{ml}$ of extractant (methanol). $10 \mathrm{~mL}$ of the leaf extract was centrifuged at 10,000 $\mathrm{rpm}$ for 10 minutes. The collected pellet was mixed with methanol. The mixture was centrifuged at 5000 $\mathrm{rpm}$ for $10 \mathrm{~min}$. the absorbance value of supernatant was measured using UV-spectrometer (UV-2450, Shimadzu) at $663 \mathrm{~nm}$ (Chlorophyll a) and $645 \mathrm{~nm}$ (Chlorophyll b).

\section{Analysis of physicochemical properties}

$10 \mathrm{~g}$ of treated and untreated sludge was taken and centrifuged at $10,000 \mathrm{rpm}$ for $20 \mathrm{~min}$. the pellet was discarded and the $\mathrm{pH}$ of supernatant was analysed by $\mathrm{pH}$ meter (ELICO Model-107). The assessment of $\mathrm{pH}$, ammoniacal nitrogen, potassium and phosphate were followed by $\mathrm{APHA}^{16}$ method. Heavy metals ( $\mathrm{Ar}, \mathrm{Cd}, \mathrm{Pb}, \mathrm{Hg}$, $\mathrm{Ni}$ and $\mathrm{Cr}$ ) were assessed using Atomic Absorption Spectrophotometer (1983-400 HGA 900/AS 800 Perkin Elmer) and multi-Element Standard (MERCK$112837)^{17}$. Table 2 and 3 show the physicochemical parameters of raw sludge, red soil and pre-treated ETP sludge. 


\section{Statistical analysis}

Experiments were carried out with triplicates. Results are presented with means \pm standard errors for all the three experiments.

\section{Analysis of seed germination and plant growth}

Ten numbers of seeds were soaked in a separate pot under $1 \mathrm{~cm}$ depth. These seeds were then spilled with water. Table 4 shows the percentage of the measurement of seed germination all the pre-treated sludge (C1, C2, C3, C4, C5 and C6). No fertilizers were used. Shoot and root length, dry and fresh weight of plant were measured after 30 , 60 , and 90 DAS. After the flowering stage, numbers of petals were counted after 45 DAS. On the $90^{\text {th }}$ day, weight of a seed per plant and the total no of 25 seeds per plant were measured ${ }^{18}$.

\section{RESULTS AND DISCUSSION}

Table 5 shows the physicochemical parameters of post-harvested soil after the phytoremediation with Helianthus annuus. In the pre-treated sludge, there was less variation in $\mathrm{pH}$ from 7.3 to 7.85 which resulted in high metal binding with soil, thereby achieving further extraction of metal through phytoremediation. According to Chaney et al., ${ }^{19}$ due to pre-liming of soil phytoextraction of metals had been reduced. In the treatment of $\mathrm{C} 2$ and $\mathrm{C} 3$, there was a reduction of potassium (12 mg/ $\mathrm{kg}, 16 \mathrm{mg} / \mathrm{kg}$ ) and phosphate (53 mg/kg, $61 \mathrm{mg} / \mathrm{kg}$ ), but in $\mathrm{C} 4$ and $\mathrm{C} 5$, the micro-organisms in the soil were unable to uptake these minerals, due to the high concentration of sludge ${ }^{20}$. Helianthus annuus was able to uptake $\mathrm{Pb}$ and Ni from ETP mixed soil (72 mg/kg and 44,410 mg/kg), which was quite low compared to the plant Catharanthus roseus which up took $\mathrm{Pb}$ and $\mathrm{Ni}$ by $67.34 \mathrm{mg} / \mathrm{kg}$ and 45.75 $\mathrm{mg} / \mathrm{kg}^{21}$. Helianthus annuus was able to survive and uptake chromium (183704 mg/kg) from pre-treated sludge. Cynodon dactylon (L.) Pers., Vetiveria nemoralis (A.) Camus, Echinochloa colonum (L.) Link., Phyllanthus reticulates Poir., Pluchea indica Less., and Amaranthus viridis were removes low amount of chromium from the soil ${ }^{22}$. From the pre-treated sludge, Helianthus annuus was able to remove $12 \%$ of $\mathrm{Cd}$, similarly to the plant of Thlaspi caerulescens ${ }^{23}$. Production of chlorophyll was above $40 \%$ in the presence of chromium which was similar to the plant Sorghum ${ }^{24}$.

Figure 1 and 2 show fresh and dry weight of plants that were analysed after $30^{\text {th }}, 60^{\text {th }}$ and $90^{\text {th }}$ day of seedling. When compared to all the six treatments control (C1) showed more significant result than $\mathrm{C} 2$, C3, C4 and C5. The maximum weight was observed in $\mathrm{C} 2$ and $\mathrm{C} 3$ treatment. Minimum weight was observed in C5. There was no growth in the treatment C6. Maximum lethal of plants occurred in higher concentration of chromium than in the lower concentration. This might be the result of deficiency of nutrients and water uptake ${ }^{25}$. Fresh and dry weight of Helianthus annuus the soil mixed with ETP sludge was higher compared with rice plants as reported by Sharma ${ }^{25}$ and grown rice plants on $\mathrm{Cr}$ contaminated soil.

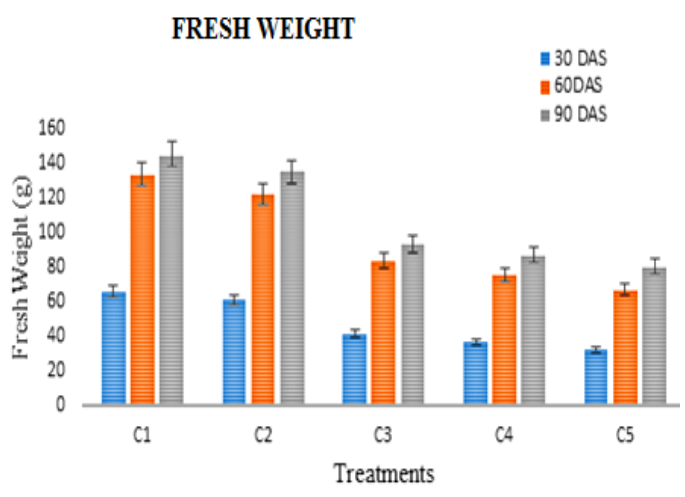

Fig. 1. Fresh weight of Helianthus annuus grown on pre-treated ETP sludge $\left(30^{\text {th }}, 60^{\text {th }}, 90^{\text {th }}\right.$ DAS)

DRY WEIGHT

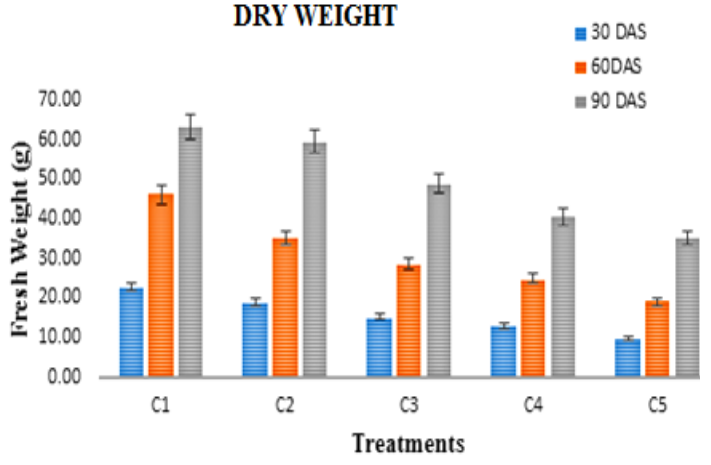

Fig. 2. Dry weight of Helianthus annuus grown on pre-treated ETP sludge $\left(30^{\text {th }}, 60^{\text {th }}, 90^{\text {th }}\right.$ DAS $)$

Figure 3 and 4 show the root and shoot length of plants that were decreased according to the concentration of Chromium. In high concentration 
of chromium, the length of roots and shoots were less. A significant result was observed in control $\mathrm{C} 1$ than C2 and C3. Minimum root and shoot length was observed in C5 treatment. The results of root and shoot length of Helianthus annuus were identical with the tomato and brinjal plants, showing less growth with $\mathrm{Cr}$ concentration of $200 \mathrm{mg} / \mathrm{L}^{26}$.

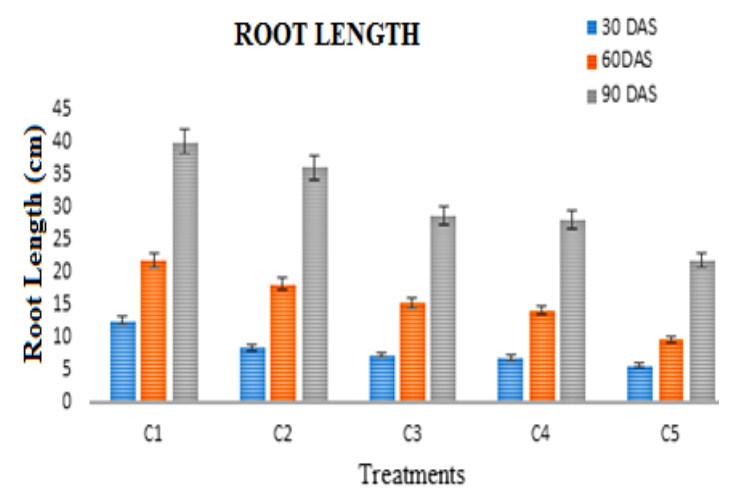

Fig. 3. Root length of Helianthus annuus grown on pre-treated ETP sludge $\left(\mathbf{3 0 ^ { \text { th } }}, \mathbf{6 0 ^ { \text { th } }}, \mathbf{9 0 ^ { \text { th } }}\right.$ DAS)



Fig. 4. Shoot length of Helianthus annuus grown on pre-treated ETP sludge $\left(30^{\text {th }}, 60^{\text {th }}, 90^{\text {th }}\right.$ DAS $)$

Figure 5 and 6 show the weight of a seed per plant and weight of 25 seeds per plant that were reduced gradually based on the concentration of heavy metals. Treatment C1 showed maximum weight of seeds when compared to others. C5 showed minimum weight of seeds which was high in heavy metal concentration ( $\mathrm{Ar}, \mathrm{Cd}, \mathrm{Pb}, \mathrm{Hg}, \mathrm{Ni}$ and $\mathrm{Cr}$ ). The concentration of chromium in sludge was higher than other heavy metals. Nitrogen was a part of biomolecules (proteins and nucleic acids), hence deficiency of nitrogen prohibited the growth and yield of plants ${ }^{27}$.
WEIGHT OF PER SEED PER PLANT

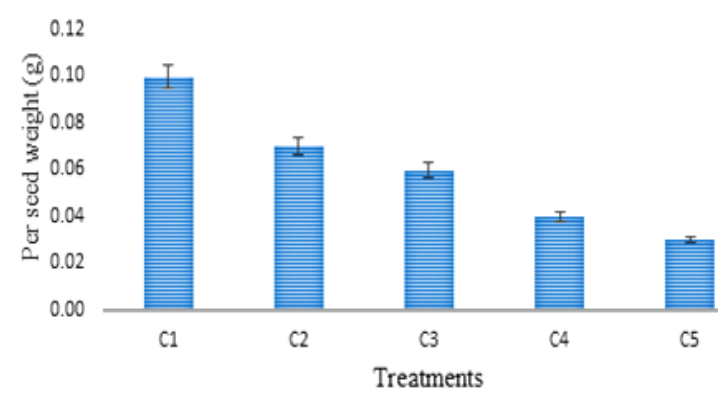

Fig. 5. Weight of a seed per plant (Helianthus annuus) grown on pre-treated ETP sludge

WEIGHT OF 25 SEEDS PER PLANT

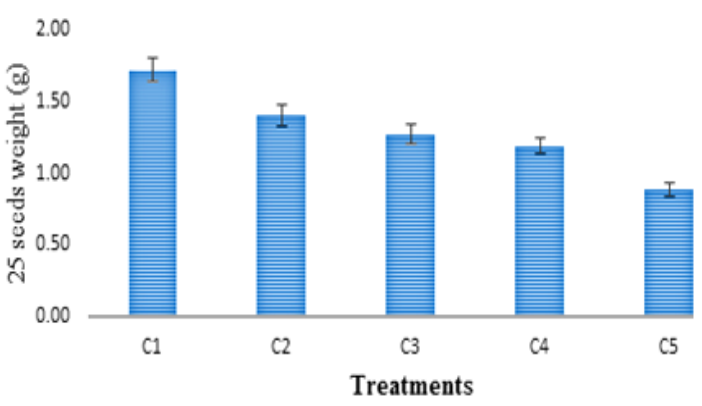

Fig. 6. Weight of 25 seeds per plant (Helianthus annuus) grown on pre-treated ETP sludge

Table 1: Treatment of ETP mixed with red soil

\begin{tabular}{lc}
\hline Treatments & Particulars \\
\hline Treatment-1 (C1) & Red soil 10 Kg (control) \\
Treatment-2 (C2) & $8 \mathrm{Kg}$ of Red soil $+2 \mathrm{Kg}$ of ETP \\
Treatment-3 (C3) & $6 \mathrm{Kg}$ of Red soil $+4 \mathrm{Kg}$ of ETP \\
Treatment-4 (C4) & $4 \mathrm{Kg}$ of Red soil + $6 \mathrm{Kg}$ of ETP \\
Treatment-5 (C5) & $2 \mathrm{Kg}$ of Red soil + 8 Kg of ETP \\
Treatment-6 (C6) & $10 \mathrm{Kg}$ of ETP \\
\hline
\end{tabular}

Table 2: Physicochemical properties of ETP before treatment

\begin{tabular}{cccc}
\hline S.NO & Parameters & Red soil & ETP \\
\hline 1 & $\mathrm{pH}$ & $7.3 \pm 0.01$ & $7.7 \pm 0.02$ \\
2 & Ammoniacal Nitrogen & $10.45 \pm 1.26$ & $95 \pm 0.89$ \\
& $(\mathrm{mg} / \mathrm{kg})$ & & \\
3 & Phosphate $(\mathrm{mg} / \mathrm{kg})$ & $12.68 \pm 0.56$ & $86 \pm 0.92$ \\
4 & Potassium $(\mathrm{mg} / \mathrm{kg})$ & $0.15 \pm 0.06$ & $26 \pm 0.18$ \\
5 & Arsenic $(\mathrm{mg} / \mathrm{kg})$ & $0.05 \pm 0.01$ & $32.12 \pm 1.64$ \\
6 & Cadmium $(\mathrm{mg} / \mathrm{kg})$ & $5.3 \pm 0.26$ & $47.2 \pm 2.23$ \\
7 & Lead $(\mathrm{mg} / \mathrm{kg})$ & $0.03 \pm 0.0$ & $89.75 \pm 3.21$ \\
8 & Mercury $(\mathrm{mg} / \mathrm{kg})$ & $0.10 \pm 0.18$ & $1.10 \pm 0.26$ \\
9 & Nickel $(\mathrm{g} / \mathrm{kg})$ & $\mathrm{ND}$ & $49.56 \pm 5.10$ \\
10 & Chromium $(\mathrm{g} / \mathrm{kg})$ & $\mathrm{ND}$ & $313.1 \pm 3.36$ \\
\hline
\end{tabular}


Table 3: Physicochemical properties of ETP pre-treated sludge after 30 days

\begin{tabular}{|c|c|c|c|c|c|c|c|}
\hline \multirow[t]{2}{*}{ S.NO } & \multirow[t]{2}{*}{ Parameters } & \multirow[b]{2}{*}{$\mathrm{C} 1$} & \multicolumn{5}{|c|}{ Treatments } \\
\hline & & & $\mathrm{C} 2$ & C3 & C4 & C5 & C6 \\
\hline 1 & $\mathrm{pH}$ & $7.3 \pm 0.10$ & $7.85 \pm 0.12$ & $7.66 \pm 0.12$ & $7.63 \pm$ & $7.60 \pm 0.05$ & $7.7 \pm 0.02$ \\
\hline 2 & $\begin{array}{c}\text { Ammoniacal Nitrogen } \\
(\mathrm{mg} / \mathrm{kg})\end{array}$ & $10.45 \pm$ & $62 \pm 1.06$ & $74 \pm 1$ & $86 \pm$ & 78 & \\
\hline 3 & Phosphate (mg/kg) & $12.68 \pm$ & $53 \pm$ & 6 & $68=$ & $75 \pm$ & $86 \pm 0.92$ \\
\hline 4 & Potassium ( & $0.15 \pm$ & $12 \pm$ & & & $20 \pm$ & $26 \pm 0.18$ \\
\hline 5 & Arsen & $0.05 \pm 0$ & $15 \pm$ & & & $28 \pm$ & $32.12 \pm 1.64$ \\
\hline 6 & Cadmic & $5.3 \pm C$ & $32 \pm$ & $35=$ & $38=$ & $41 \pm$ & $47.2 \pm 2.23$ \\
\hline 7 & Lead & $0.03 \pm 0$ & $68 \pm$ & $72 \pm$ & $76=$ & $80 \pm 1.51$ & $89.75 \pm 3.21$ \\
\hline 8 & Merc & 1 & & 0.2 & 0.10 & .001 & $1.10 \pm 0.01$ \\
\hline 9 & & ND & 43.22 & $44.41 \pm$ & 45.58 & $46.99 \pm 4.28$ & $49.56 \pm 5.10$ \\
\hline 10 & Chromium (g/kg) & ND & $286.1 \pm 3.10$ & $306.2 \pm 4.240$ & $308.6 \pm 2.450$ & $310.8 \pm 2.10$ & $313.1 \pm 3.36$ \\
\hline
\end{tabular}

Table 4: Germination of seeds on the pre-treated ETP +Soil

\begin{tabular}{lcc}
\hline Treatments & $\begin{array}{c}\text { Seed Germination percentage(\%) } \\
\text { 7th DAS }\end{array}$ & \begin{tabular}{c} 
14th DAS \\
\hline Treatment-1 (C1)
\end{tabular} \\
Treatment-2 (C2) & 88 & 98 \\
Treatment-3 (C3) & 50 & 85 \\
Treatment-4 (C4) & 25 & 55 \\
Treatment-5 (C5) & 12 & 28 \\
Treatment-6 (C6) & 0 & 13 \\
\hline
\end{tabular}

Table 5: Physicochemical properties of post harvested soil (1st stage) (Chromium removal)

\begin{tabular}{ccccccc}
\hline S.NO & Parameters & C1 & C2 & C3 & C4 & C5 \\
\hline 1 & pH & $7.03 \pm 0.01$ & $7.06 \pm 0.09$ & $7.08 \pm 0.12$ & $7.07 \pm 0.15$ & $7.66 \pm 0.17$ \\
2 & Ammoniacal Nitrogen $(\mathrm{mg} / \mathrm{kg})$ & $7.75 \pm 0.21$ & $58 \pm 1.22$ & $66 \pm 2.26$ & $71 \pm 2.10$ & $78 \pm 2.09$ \\
3 & Phosphate $(\mathrm{mg} / \mathrm{kg})$ & $8.21 \pm 0.5$ & $47 \pm 1.55$ & $56 \pm 1.58$ & $63 \pm 2.21$ & $72 \pm 2.35$ \\
4 & Potassium $(\mathrm{mg} / \mathrm{kg})$ & $0.03 \pm 0.001$ & $9 \pm 0.06$ & $12 \pm 0.36$ & $15 \pm 0.85$ & $18 \pm 0.77$ \\
5 & Arsenic $(\mathrm{mg} / \mathrm{kg})$ & $0.02 \pm 0.001$ & $10 \pm 0.81$ & $16 \pm 0.88$ & $20 \pm 1.09$ & $24 \pm 1.10$ \\
6 & Cadmium $(\mathrm{mg} / \mathrm{kg})$ & $3.13 \pm 0.12$ & $27 \pm 1.26$ & $30 \pm 1.41$ & $33 \pm 1.36$ & $39 \pm 1.58$ \\
7 & Lead $(\mathrm{mg} / \mathrm{kg})$ & $0.02 \pm 0.001$ & $60 \pm 1.64$ & $68 \pm 1.76$ & $70 \pm 2.12$ & $77 \pm 2.35$ \\
8 & Mercury $(\mathrm{mg} / \mathrm{kg})$ & $0.05 \pm 0.001$ & $0.10 \pm 0.001$ & $0.15 \pm 0.001$ & $0.09 \pm 0.001$ & $0.12 \pm 0.01$ \\
9 & Nickel $(\mathrm{g} / \mathrm{kg})$ & ND & $40.57 \pm 1.54$ & $42.37 \pm 2.68$ & $44.45 \pm 3.15$ & $45.87 \pm 1.22$ \\
10 & Chromium $(\mathrm{g} / \mathrm{kg})$ & ND & $110.8 \pm 1.36$ & $122.5 \pm 2.76$ & $202.5 \pm 3.46$ & $301.8 \pm 2.36$ \\
\hline
\end{tabular}

\section{CONCLUSION}

The present investigation concluded that the Helianthus annuus could be used for the removal of chromium from the ETP sludge. The ETP sludge might improve the growth and yield of Helianthus annuus. This technology could be eco-friendly, pollution free and cheap.

\section{ACKNOWLEDGEMENT}

We are thankful to Karpagam Academy of Higher Education, Coimbatore for providing the support to carryout the research. 


\section{REFERENCES}

1. Mathur, A.K.; lijima, K.K.; Tandon, S.K.; Dikshith, T.S.; Bull. Environ. Contam. Toxicol., 1977, 17, 241-248.

2. Koropatnick, J.; Leibbrandt, M.E.I.; Biochem. Aspects Springer., 1995, 115, 93-120.

3. Ajmal, M.; Rao, W.A.; Peyton, J.N.; Bioremed. J., 1996, 6, 205-215.

4. Langard, S.; Internat. Arch. of Occup. Environ. Heal., 1980, 46, 1-9.

5. U.S. Environmental Protection Agency Washington, DC., 1998, 83(1) 16065.

6. Carmina, G.; Roc, R.; Antonio, H.; David, W.; Bernal, M.; Ramon, S.; Juan, N.; Biochem. Biophys. Res. Commun., 2003, 303, 440-445.

7. David, S.; Michael, B.; Nanda, K.; Viatcheslav, D.; Burt, E.; Ilan, C.; Ilya, R.; Nat. Biotechnol., 1995, 13, $468-474$.

8. MADEP (Massacgysetts Department of Environmental Protection Publication): Massachusetts Contingency Plan (MCP), Boston., 1993.

9. Singh, O.; Jain R.; Appl. Microbiol. Biotechnol., 2003, 63, 128-135.

10. Ilya, R.; Robert, S.; David, S.; Curr. Opin. Biotechnol., 1997, 8, 221-226.

11. Elizabeth, P.; Pub. Med. Web. Sci., 2005, 56, 5-39.

12. Prasad, M.N.V.; Freitas H.; Electron. J. Biotechnol., 2003, 6, 285-321.

13. Schnoor, J.L.; Technol. Eval. Report., 2002, 1, 252-630.

14. Alireza, H.; Farhang, M.; Iran. J. Plant Phy.,
2010, 2, 95-99.

15. Clesceri, L.S.; Greenberg AE.; Trussel, R.R.; American Public Health Association, Washington, DC., 1989.

16. Arnon DI.; Plant physiol., 1949, 24, 1-15.

17. Fraile A.; Penche S.; González F.; Chem. Ecol., 2005, 21, 61-75.

18. Francis E.; I. J. S. E. R., 2017, 1, 1751-1757.

19. Chaney, R.L.; Li, Y.M.; Angle, J.S.; Baker, A.J.M.; Reeves, R.D.; Brown, S.L.; Homer, F.A.; Malik, M.; and Chin, M.; Phytoremediation of contaminated soils and water. CRC Boca Raton, FL: CRC press., 2000, 131-160.

20. Rauser W. E.; Cell Biochem. Biophys., 1999, 31, 19-48.

21. Subhashini, V.;Swamy. A. V. V. S.; U. J. E. R. T., 2013, 3, 465-472.

22. Pantawat S.; Wasant P.; Sutha K.; Eakalak K.; Water, Air, Soil Pollut., 2006, 6, 191-206.

23. Gerard, E.; Echevarria, G.; Sterckeman, T.; Morel, J. L.P.; J. Environ. Qual., 2000, 29, 1117-1123.

24. Revathi, K.; Haribabu, T.E.; Sudha. P.N.; I. J. E. S. T., 2011, 2, 417-428.

25. Sharma, D.C.; Mehrotra, S.C.; Indian J. Environ. Health., 1993, 35, 330-342.

26. Purohit, S.; Varghese, T.M.; Kumari, M.; Indian J. Plant Physiol., 2003, 8, 17-22.

27. Chatterjee, J.; Chatterjee, C.; Environ. Pollut., 2000, 109, 69-74. 